\title{
The reproductive performance of the Red-Algae shrimp Leander paulensis (Ortmann, 1897) (Decapoda, Palaemonidae) and the effect of post-spawning female weight gain on weight-dependent parameters
}

\author{
Uwe Zimmermann ${ }^{1,2}$, Fabricio Lopes Carvalho ${ }^{2,3}$, Fernando L. Mantelatto ${ }^{2, *}$
}

\author{
${ }^{1}$ Eberhard Karls-University Tübingen, Faculty of Science, Department of Biology \\ (Auf der Morgenstelle 28, 72076 Tübingen, Germany) \\ ${ }^{2}$ Universidade de São Paulo (USP), Faculdade de Filosofia, Ciências e Letras de Ribeirão Preto (FFCLRP), Departamento de Biologia, \\ Laboratório de Bioecologia e Sistemática de Crustáceos (LBSC) \\ (Av. Bandeirantes, 3900, Ribeirão Preto, 14040-901, São Paulo, Brazil) \\ ${ }^{3}$ Universidade Federal do Sul da Bahia (UFSB), Instituto de Humanidades, Artes e Ciências Jorge Amado (IHAC-JA) \\ (Rod. Ilhéus-Vitória da Conquista, km 39, BR 415, 45613-204, Ferradas, Itabuna, Bahia, Brazil) \\ *Corresponding author: flmantel@usp.br
}

Financial Support: FAPESP (Temático Biota 2010/50188-8) CAPES (Ciências do Mar II Proc. 2005/2014 - 23038.004308/201414)

CNPq (DR 140199/2011-0 and PQ 302748/2010-5; 304968/2014-5)

\section{Abstract}

Decapod species have evolved with a variety of reproductive strategies. In this study reproductive features of the palaemonid shrimp Leander paulensis were investigated. Individuals were collected in the coastal region of Ubatuba, São Paulo, Brazil. In all, 46 ovigerous females were examined in terms of the following reproductive traits: fecundity, reproductive output, brood loss and egg volume. Leander paulensis produces a large number of small eggs with an average fecundity of $635 \pm 246$ eggs. Egg volume increased significantly from early $\left(0.034 \pm 0.008 \mathrm{~mm}^{3}\right)$ to late development stage $\left(0.05 \pm 0.012 \mathrm{~mm}^{3}\right)$. The reproductive output did not correlate with female size. The weight of females bearing stage 2 eggs was significantly higher than that of females carrying stage 1 eggs. We assume that the reason for this weight gain is the recovery of female reserves that have been depleted for egg production. Moreover, we emphasize that this weight gain must be considered when evaluating weight-dependent variables such as reproductive output or brood loss in relation to female weight. Otherwise, an overestimation of these variables might lead to inaccurate results.

Descriptors: Brood loss, Caridea, Egg volume, Fecundity, Reproductive output.

\section{RESUMo}

Decápodes desenvolveram uma ampla variedade de estratégias reprodutivas. Neste estudo foram investigadas características reprodutivas da espécie de Palaemonidae Leander paulensis. Os indivíduos foram coletados na região costeira de Ubatuba, São Paulo, Brasil. Foram examinadas 46 fêmeas ovígeras quanto aos seguintes aspectos reprodutivos: fecundidade, investimento reprodutivo, perda de ovos e volume dos ovos. Leander paulensis produz uma grande quantidade de pequenos ovos, com fecundidade média de $635 \pm 246$ ovos. O volume dos ovos aumentou significativamente quando comparado o estágio inicial $(0.034 \pm 0.008$ $\left.\mathrm{mm}^{3}\right)$ com o estágio final de desenvolvimento $(0.05 \pm$ $\left.0.012 \mathrm{~mm}^{3}\right)$. O investimento reprodutivo não apresentou correlação com o tamanho das fêmeas. Fêmeas com ovos no estágio 2 apresentaram massa corpórea seca significativamente maior que aquelas carregando ovos no estágio inicial. Esse aumento de massa parece ser decorrente da recuperação de reservas energéticas das fêmeas, que teriam sido utilizadas durante a produção de ovos. Além disso, deve-se considerar neste tipo de avaliação o aumento da massa corpórea em relação ao investimento reprodutivo, assim como da perda de ovos relacionada à massa das fêmeas ou qualquer outra variável dependente do peso.

Descritores: Fecundidade, Caridea, Perda de ovos, Volume de ovos, Investimento reprodutivo. 


\section{INTRODUCTION}

There are many reproductive strategies among decapods, and these manifest as differences in parameters such as fecundity and breeding frequency, which are directly related to the species' life strategy (OH; HARTNOLL, 2004). Caridean shrimps are not an exception to this scenario, with some species, such as Macrobrachium potiuna (NAZARI et al., 2003) and Synalpheus pectiniger (COREY; REID, 1991), producing few but larger eggs, and others, such as Macrobrachium olfersii and Pontonia margarita, carrying a great number of relatively small eggs (COREY; REID, 1991). Differences in reproductive strategies can also occur intraspecifically, depending on environmental factors such as salinity (JANAS; MAŃKUCKA, 2010) or temperature and season (BODDEKE, 1982; OH; HARTNOLL, 2004). Other examples and variations among these genera and congeners are discussed in PAVANELLI et al. (2008) and TAMBURUS et al. (2012).

The genus Leander DESMAREST, 1849, is composed of five species distributed in different regions (DE GRAVE; FRANSEN, 2011). Leander paulensis ORTMANN, 1897, is a small shrimp that occurs in shallow marine waters of the western Atlantic from Florida, USA to Paraná, Brazil (CARVALHO et al., 2014). It inhabits sand and rock bottoms with algae up to a depth of $16 \mathrm{~m}$ (RAMOS-PORTO, 1986). Studies regarding $L$. paulensis have focused on the composition of crustacean fauna of certain areas (COSTA et al., 2000; COELHO et al., 2006; ALMEIDA et al., 2006, 2007a, b; MCCARTHY et al., 2012), taxonomy and geographical distribution (MANNING, 1961; RAMOSPORTO, 1986; ABELE; KIM, 1989; RAMOS-PORTO; COELHO, 1998; CARVALHO et al., 2014). Some ecological features, such as reproductive period, fecundity, egg volume and brood volume (BAUER, 1989, 1991; COREY; REID, 1991), have been addressed in the congeneric species Leander tenuicornis. However, Leander paulensis remains completely unknown in terms of its reproductive strategy. Considering that fecundity is an expressive measure of reproductive potential and contributes to the understanding of reproductive performance, the aim of the present paper is to analyze female weight gain during egg incubation, fecundity and investment per reproductive event in Leander paulensis.

\section{MATERIAL AND METHODS}

All specimens were collected in April 2013 at Lamberto beach $\left(23^{\circ} 29^{\prime} 56^{\prime \prime} \mathrm{S}, 45^{\circ} 07^{\prime} 04^{\prime \prime} \mathrm{W}\right)$, a protected area that lies in the sheltered Flamengo bay, south of
Ubatuba, São Paulo State, Brazil (Figure 1). In total, 46 ovigerous females were captured using a hand push net at a depth of 0.5 to $1 \mathrm{~m}$ and were identified according to Ramos-Porto (1986). All specimens were kept in $80 \%$ ethanol for the duration of the study.

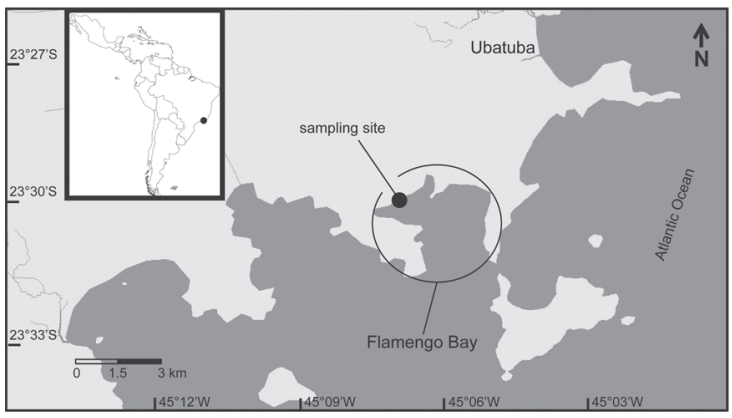

Figure 1. Location of the sampling site in the Flamengo Bay in the southern region of Ubatuba, State of São Paulo, Brazil.

Eggs of all females were gently removed, using fine forceps under a Leica $^{\circledR}$ stereomicroscope M205C. The measurement of eggs and females, and the counting and classification of eggs, were performed under the stereomicroscope with the aid of the Leica Application Suite $^{\circledR}$ (v 3.8.0). Female carapace length was measured from the post-orbital margin to the posterior border of the carapace. Eggs were counted and classified into two stages: stage 1 (early development) without eyespots and stage 2 (late development) with visible eyespots (COREY; REID, 1991). Ten eggs from each female were randomly chosen for measurement of their major and minor axis and the volume of each egg was quantified using the volume formula of oblate spheroids (cf. TURNER; LAWRENCE, 1979): $\mathrm{EV}=4 / 3 * \pi * \mathrm{EL} / 2 *(\mathrm{EW} / 2)^{2}$, where $\mathrm{EV}=$ egg volume, $\mathrm{EL}=$ egg length and $\mathrm{EW}=$ egg width. For fecundity estimation, an ANCOVA was performed to check whether there is a loss of eggs from stage 1 to stage 2 . As the results showed no significant difference (see results section), eggs of all 46 females were considered, regardless of their stage. Fecundity was thus determined as the total number of eggs attached to the abdomen of each female.

Egg samples and females were weighed separately. Female weight was quantified after removing all the eggs from the female's abdomen. All weight measures were dry weight values and were quantified after 48 hours of oven drying at $50^{\circ} \mathrm{C}$ (Fanem oven model $315 \mathrm{SE}$ ). Brood weight was determined as the total weight of the entire egg batch. The reproductive output (RO) was estimated for one single spawning event (one brood) and is 
therefore defined herein as investment per reproductive event. To determine the reproductive output of each female, brood dry weight was divided by the females' dry weight. An ANCOVA was performed to check whether reproductive output differed between females of stage 1 and females of stage 2 eggs. As the reproductive output was significantly lower for females carrying stage 2 eggs (see results section), only females carrying stage 1 eggs were used to determine the reproductive investment. Additionally, differences in female weight between individuals of stage 1 and 2 were tested by performing ANCOVA.

The Akaike Information Criterion (AIC) was used to choose the simplest model of ANCOVA that could be used (with or without interaction). All ANCOVA were performed with sum of squares type III, having carapace length as the covariate. The variables were linearized (ln) for all ANCOVA. A Student's $t$-test was performed to verify whether there is any difference between the volume of eggs in stage 1 and stage 2 . A linear regression analysis was conducted to check for a relationship between the reproductive output and carapace length of females. Power regression and the coefficient of determination were obtained and displayed whenever a significant correlation was observed.

The significance level of 0.05 was adopted for all analyses. The results are displayed as the mean \pm standard deviation. All statistical analyses were performed using the R program version 3.0.1 (car package) (FOX; WEISBERG, 2011).

\section{RESULTS}

\section{Female Size AND WeIght}

Carapace length varied from $4.27 \mathrm{~mm}$ to $6.92 \mathrm{~mm}$ (mean $5.50 \pm 0.63 \mathrm{~mm}$ ). Female weight varied from $16.3 \mathrm{mg}$ to $67.6 \mathrm{mg}(39.55 \pm 13.06 \mathrm{mg})$ for stage 1 and from $21.3 \mathrm{mg}$ to $81.8 \mathrm{mg}(50.99 \pm 18.70 \mathrm{mg})$ for stage 2. The mean female weight of both stages combined was $42.96 \mathrm{mg}$ ( \pm 15.66$)$. Females of stage 2 eggs were significantly heavier than females of stage 1 eggs $(\mathrm{F}=36.4$, d.f. $=1,43, p<0.01)$. The carapace length $v s$. weight relationship was described by a power function (Figure 2). The equation for stage 1 was $\mathrm{FW}=$ $0.2178 * \mathrm{CL}^{3.0407}\left(\mathrm{R}^{2}=0.859\right)$ and $\mathrm{FW}=0.3986 * \mathrm{CL}^{2.8062}$ $\left(\mathrm{R}^{2}=0.945\right)$ for stage 2 , where $\mathrm{FW}=$ female weight and $\mathrm{CL}=$ carapace length.

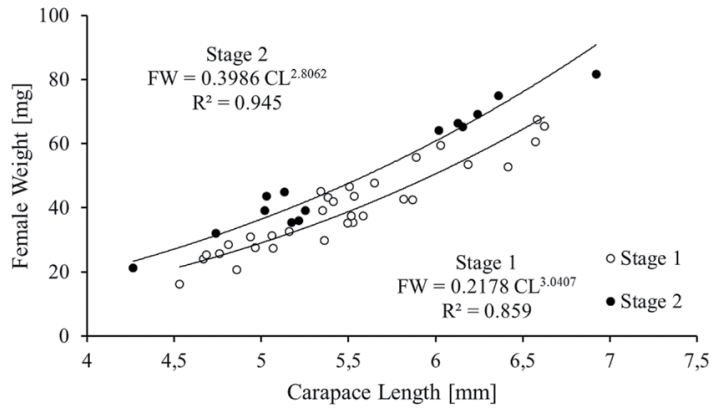

Figure 2. Power function of female weight and carapace length. The weight of females with stage 2 eggs is significantly higher than the weight of females with stage 1 eggs $(\mathrm{F}=36.4$, d.f. $=1,43, p<0.01)$. Female weight does not include egg weight. $\mathrm{FW}=$ female weight; $\mathrm{CL}=$ carapace length.

\section{FECUNDITY}

Of the 46 females examined, 32 females carried eggs of stage 1 and 14 carried eggs of stage 2 . Fecundity showed a strong correlation with carapace length which could be described by a power function (Figure 3). There was no significant difference in the number of eggs between stages 1 and $2(\mathrm{~F}=0.32$, d.f. $=1,43, p=0.58)$. The number of eggs ranged from 227 (smallest female, $\mathrm{CL}=4.27 \mathrm{~mm}$ ) to 1360 (largest female, $\mathrm{CL}=6.92 \mathrm{~mm}$ ) averaging $635 \pm 246$ eggs. The power regression equation representing the data of both egg stages is $\mathrm{FW}=2.5857$ * $\mathrm{CL}^{3.1997}\left(\mathrm{R}^{2}=0.8922\right)$, where $\mathrm{F}=$ fecundity (number of eggs) and $\mathrm{CL}=$ carapace length $(\mathrm{mm})$.

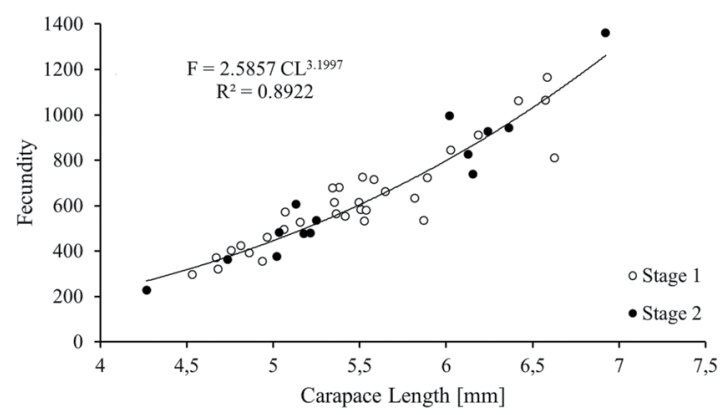

Figure 3. Fecundity in relation to carapace length. A power regression is applied to the individuals of both egg stages combined. The number of eggs does not vary significantly from stage 1 to $2(\mathrm{~F}=0.32$, d.f. $=1,43, p=0.58) . \mathrm{F}=$ fecundity; $\mathrm{CL}=$ carapace length.

\section{EGG VOLUME}

The mean egg volumes of stages 1 and 2 were $0.034 \mathrm{~mm}^{3}( \pm 0.008)$ and $0.050 \mathrm{~mm}^{3}( \pm 0.012)$, respectively, with volume values ranging from 0.013 to $0.055 \mathrm{~mm}^{3}$ for 
stage 1 and from 0.018 to $0.076 \mathrm{~mm}^{3}$ for stage 2 . There was a significant increase in egg volume from stage 1 to stage $2(\mathrm{t}=16.3$, d.f. $=458, p<0.01)$ (Figure 4$)$. The outlier in stage 2 is from a female whose eggs were poorly developed and small, although eyespots were visible.

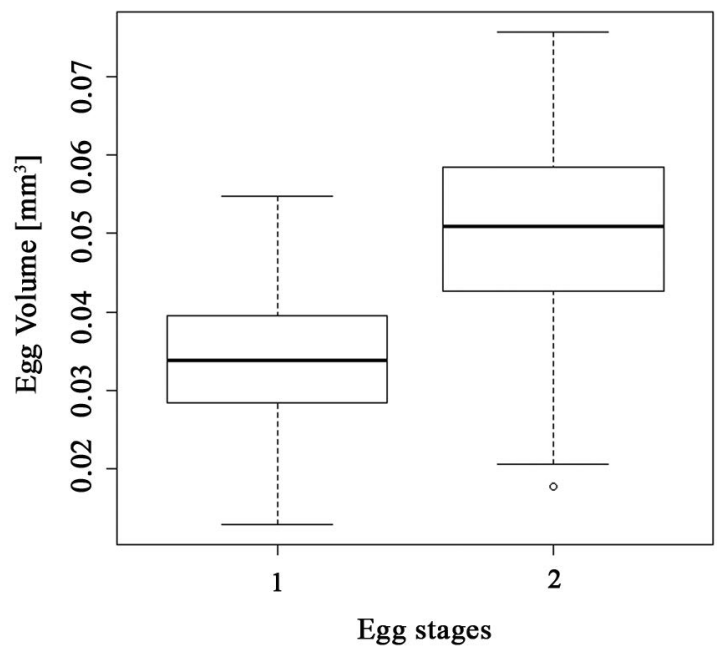

Figure 4. Boxplot of egg volume at stage 1 and 2 . The egg volume of stage 2 eggs is significantly higher than that of stage 1 eggs $(\mathrm{t}=16.3$, d.f. $=458, p<0.01)$.

\section{REPRODUCTIVE OUTPUT}

As the reproductive output was significantly lower for females bearing stage 2 eggs $(F=7.28$, d.f. $=1,43$, $p<0.01$ ), only females carrying stage 1 eggs were used to calculate the reproductive investment. The values of reproductive output per reproductive event ranged from $4.8 \%(\mathrm{CL}=4.94 \mathrm{~mm})$ to $28.5 \%(\mathrm{CL}=4.86 \mathrm{~mm})$ of egg weight relative to female weight (Figure 5). The mean value was $14.2 \pm 5.4 \%$. A linear regression test showed no significant relationship between the reproductive output and carapace length $(\mathrm{F}=1.75$, d.f $=44, p=0.19)$, which indicates that the reproductive output does not depend on female size in this species.

\section{DISCUSSION}

\section{Female WeIGHT GAIN DURING INCUBATION}

Females carrying stage 2 eggs exhibit a significantly higher weight than those carrying stage 1 eggs. To the best of our knowledge, this aspect has never been shown in caridean species. In terms of energy (i.e. nutritional resources), spawning is very costly and uses up accumulated reserves. At the beginning of the incubation period, females have a lower weight as nutritional reserves

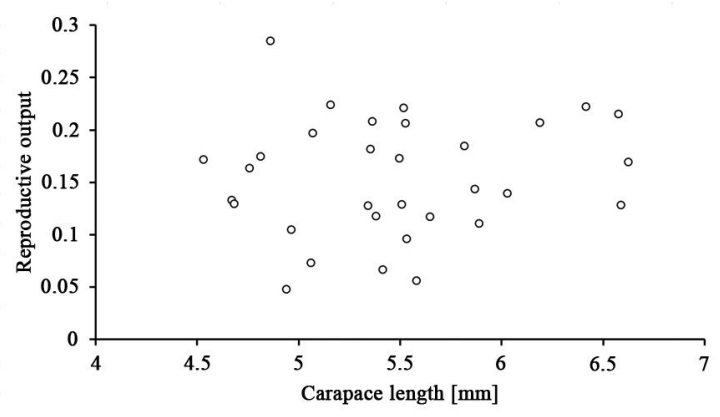

Figure 5. Reproductive output and carapace length of females carrying eggs at stage 1 . No significant relationship could be detected $(\mathrm{F}=1.75$, d.f. $=44, p=0.19)$.

were invested into egg production. During egg incubation and maturation weight is regained as food intake is used to build up new reserves. Moreover, females may rebuild their gonads after spawning, which additionally increases female weight. However, gonad recovery has not been analyzed in this study.

The weight gain of females during egg incubation must be considered when evaluating weight-specific variables, such as the reproductive output or egg loss. According to ANGER; MOREIRA (1998), egg loss can be estimated measuring both size and weight-specific fecundity. However, our data reveal that a weight-specific estimation of fecundity might give inaccurate results. An increase in female weight might lead to an overestimation of brood loss when regressing fecundity on female weight. Female size is less likely to change during the incubation period. Therefore, our recommendation is to analyze brood loss rather by size-specific than weight-specific fecundity.

Similar consideration is needed for the analysis of the reproductive output, since it is calculated by measuring the weight of eggs and females. Therefore, one should either rule out a weight change for females during the incubation period or consider only females of an early developmental egg stage. In our study the reproductive output was significantly lower for females bearing eggs of stage 2 . This reduction, however, cannot be explained by egg loss but is due to an increase of female weight. Thus, our results strongly recommend an estimation of reproductive output at an early stage of egg development. With proceeding, egg maturation females are more likely to have gained weight. This weight increase could give lower results for the reproductive output than if it was measured at early egg stage. If and how much female weight increases during egg incubation depends on the amount of food uptake. Variation in the degree of weight gain therefore underlies variation 
in the extent of feeding during egg incubation. If a female weight increase cannot be ruled out, we suggest quantifying exclusively the reproductive output of females with eggs of early developmental stages. To our knowledge, no further information on the effect of post-spawning female weight gain is available in the literature. Therefore, we strongly recommend this approach in future studies with other members of this group.

\section{FECUNDITY}

Fecundity and carapace length show a strong positive correlation as has been recorded for many decapod crustacean species (REID; COREY, 1991a, b). The same relationship is found in the congener Leander tenuicornis (COREY; REID, 1991) and other palaemonid shrimps (ALBERTONI et al., 2002; DA SILVA et al., 2004; BILGIN; SAMSUN, 2006; TAMBURUS et al., 2012). Although female size is likely to be the principal factor determining the fecundity of a species, other factors, such as latitudinal distribution, adaptation to habitat and season may influence fecundity as well (BODDEKE, 1982; MANTELATTO; FRANSOZO, 1997). Additionally, various biological variables, such as pleopod size in relation to body size, the number of spawns in a single reproductive period, egg mortality, and food availability may also affect fecundity (ANNALA, 1991; OH et al., 2002).

Fecundity data on a member of the genus Leander has been published by BAUER (1991) and COREY and REID (1991) for Leander tenuicornis. The mean fecundity of $L$. tenuicornis found by COREY and REID (1991) in East Florida/USA $\left(28^{\circ} 31^{\prime} \mathrm{N}, 80^{\circ} 45^{\prime} \mathrm{W}\right)$ amounts to 452 eggs per female, ranging from 181 to 640 eggs. BAUER (1991) obtained a somewhat higher fecundity on the north coast of Puerto Rico (18 $\left.29^{\prime} \mathrm{N}, 6^{\circ} 15^{\prime} \mathrm{W}\right)$ averaging $593 \pm 311$ eggs. Compared to these results, Leander paulensis from Ubatuba $\left(23^{\circ} 29^{\prime} \mathrm{S}, 45^{\circ} 07^{\prime} \mathrm{W}\right)$ achieves a slightly higher fecundity than its congener $(635 \pm 246$ eggs ranging from 227 to 1360). Carapace length by both authors is very similar (BAUER, 1991: 6.7 mm; COREY; REID, 1991: $6.42 \mathrm{~mm}$ ) and is therefore slightly higher than the mean carapace length of $L$. paulensis in this study $(5.50 \pm 0.63$ $\mathrm{mm}$, ranging from 4.27 to $6.92 \mathrm{~mm}$ ), which still permits a fecundity comparison of both species. Other palaemonids of similar size, such as Palaemonetes pugio (110 eggs ranging from 53 to 189) and Palaemon mundusnovus (former Palaemonetes intermedius) (105 eggs ranging from 52 to 168) also laid fewer eggs than L. paulensis (COREY; REID, 1991).
Brood loss is a life-history parameter playing an important role when determining fecundity per spawning event (ANGER; MOREIRA, 1998). In this study, no significant loss of eggs was observed during the spawning period examined. Similar results were found for Macrobrachium acanthurus and Palaemon carinicauda (former Exopalaemon carinicauda) $(\mathrm{OH}$; KIM, 2008; TAMBURUS et al., 2012). Tamburus et al. (2012) conjectured an efficient parental care strategy to reduce the most common causes of egg loss. Contrary to these findings, many other studies have found a significant reduction of fecundity in other palaemonid species. ANGER and MOREIRA (1998) calculated a maximum loss of eggs of $23 \%$ in Palaemon pandaliformis and Macrobrachium acanthurus. A brood loss of 38\% was estimated for Palaemon serratus by REEVE (1969) and $15-33 \%$ for Palaemon modestus (former Exopalaemon modestus) by $\mathrm{OH}$ et al. (2002). NAZARI et al. (2003) studied two freshwater prawns, Macrobrachium potiuna and $M$. olfersii, and stated that the egg loss could result in a better accommodation of the eggs in the brood pouch and, therefore, a greater circulation and better supply of oxygen. Other factors causing this loss may be mechanical stress, increase in egg volume during incubation, abrasion by the ventilatory movements of the pleopods or any intrinsic or extrinsic change during incubation period (BALASUNDARAM; PANDIAN, 1982; KURIS, 1991). Parasites can also affect brood mortality as shown by KURIS and WICKHAM (1987) for some brachyuran crabs. It is possible that disturbances such as mechanical stress are lower for the area or time period where L. paulensis females were collected since the sampling site was inside a sheltered bay. However, mechanical stress could not be controlled for in this study since collecting took place at one single sampling site and during one single spawning event. Likewise, the absence of egg loss in this study could be explained by more intensive brood care as was suggested for Macrobrachium acanthurus by TAMBURUS et al. (2012).

\section{EGG VOLUME}

Egg volume increases significantly during egg development from stage 1 to stage 2 . An increase in size during egg development is a common feature among crustaceans (DAVIS, 1965, 1966; PANDIAN, 1970; WEAR, 1974; MORAIS et al., 2002; NAZARI et al., 2003; ZHAO et al., 2007). Most authors relate this increase mainly to osmotic water uptake through the 
egg membrane (DAVIS, 1965; 1966; PANDIAN, 1970; WEHRTMANN; KATTNER, 1998; NAZARI et al., 2003; ZHAO et al., 2007). Moreover, AMSLER and GEORGE (1984) discussed metabolic water as a by-product of respiration as an additional factor.

Data on egg size of a species of the genus Leander has been published by COREY and REID (1991) and BAUER (1991) for Leander tenuicornis. For calculation of egg volume, Corey and Reid (1991) applied the formula $\mathrm{EV}=\mathrm{EL} * \pi *(\mathrm{EW} / 2)^{2}$ differing from the formula of oblate spheroids used by BAUER (1991) and in this study: $\mathrm{EV}=4 / 3 * \pi * \mathrm{EL} / 2 *(\mathrm{EW} / 2)^{2}$ with $\mathrm{EV}=$ egg volume, $\mathrm{EL}=$ egg length and $\mathrm{EW}=$ egg width. The results of the two formulas differ by the factor 1.5. To compare the egg volume data of the present study to both studies on Leander tenuicornis, egg volume values of L. tenuicornis published by COREY and REID (1991) were transformed by dividing them by 1.5 .

Results on Leander tenuicornis by BAUER (1991) and COREY and REID (1991) differ to some extent. The mean egg volume obtained by Bauer (1991) (0.028 and $0.033 \mathrm{~mm}^{3}$ for first and second egg stage, respectively; both stages without visible eyespots) on the north coast of Puerto Rico $\left(18^{\circ} 29^{\prime} \mathrm{N}, 6^{\circ} 15^{\prime} \mathrm{W}\right)$ is about a third of that found by COREY and REID (1991) $\left(0.109 \mathrm{~mm}^{3}\right)$ in East Florida/USA $\left(28^{\circ} 31^{\prime} \mathrm{N}, 80^{\circ} 45^{\prime} \mathrm{W}\right)$. An overview of egg volume, fecundity and carapace length of $L$. tenuicornis and L. paulensis is given in Table 1. Eggs of Leander paulensis $\left(0.034 \mathrm{~mm}^{3}\right)$ are much smaller than those of L. tenuicornis from a mangrove ecosystem in Florida. However, they are about the same size as eggs of L. tenuicornis from seagrass meadows in Puerto Rico. This not only implicates ecological and latitudinal factors accounting for differences between the species, but also reveals strong intraspecific variation in egg size of $L$. tenuicornis, changing with latitude and habitat. Fecundity of $L$. paulensis also resembles that of $L$. tenuicornis from Puerto Rico, however it differs from that found in Florida.
These results indicate that Leander tenuicornis may pursue different reproductive strategies in different localities. Moreover, L. paulensis and L. tenuicornis from Florida differ strongly in their reproductive traits. L. paulensis produces more but smaller eggs, whereas fecundity of L. tenuicornis is lower but egg volume is comparatively high. However, compared to L. tenuicornis from Puerto Rico, reproductive traits are very similar, implying a similar reproductive strategy, i.e. many small instead of few larger eggs.

Studies comparing different species of marine invertebrates have revealed that egg size represents an energy investment on the part of females, as larger eggs contain a higher amount of yolk (SHAKUNTALA; REDDY, 1982; MCCLINTOCK; PEARSE, 1986; CLARKE; GORE, 1993; MCEDWARD; MORGAN, 2001). This model is strongly confirmed and accounts for interspecific variation in egg size (CLARKE, 1993a). Egg size strongly influences the developing rate and the hatching size of larvae or juveniles. Larger eggs generally produce larger offspring, which may be better prepared for competition (SASTRY, 1983). Egg size is an adaptive factor for different habitat conditions, such as temperature, salinity, food supply or predation (SASTRY, 1983; MASHIKO, 1990; CLARKE, 1993b). In this context, latitudinal differences also play an important role. Several of the mentioned features presumably account for differences in fecundity and egg size of L. tenuicornis from Florida and L. paulensis. The little data available on the fecundity of the genus, however, do not permit a consistent evaluation of this trait for this taxon; populations of these species in other areas should be studied to construct a more comprehensive scenario regarding reproductive performance.

\section{REPRODUCTIVE OUTPUT}

The reproductive output of Leander paulensis shows no significant correlation with female carapace length. The absence of a significant relationship between size and reproductive output has been reported for other species of palaemonids

Table 1. Comparison of fecundity, egg volume $\left(\mathrm{mm}^{3}\right)$ and female size (carapace length in mm) of Leander tenuicornis and L. paulensis. The values of egg volume by Bauer (1991) are means of first and second egg stage, both without visible eyespot. The egg volume data of Corey and Reid (1991) was adjusted by the factor 1.5 to the volume formula applied by Bauer (1991) and in this study. For the egg volume of L. paulensis only stage 1 eggs were used in this comparison.

\begin{tabular}{lcccl}
\hline Species & $\begin{array}{c}\text { Mean fecundity } \\
\pm \text { SD (min. - max.) }\end{array}$ & $\begin{array}{c}\text { Mean egg volume (mm } \\
\pm \text { SD (min. }-\mathbf{m a x} \text { ) }\end{array}$ & $\begin{array}{c}\text { Carapace length (mm) } \\
\pm \text { SD (min. - max.) }\end{array}$ & Reference \\
\hline L. tenuicornis & $452(181-640)$ & 0.109 & $6.42(5.20-7.52)$ & Corey and Reid (1991) \\
& $593 \pm 311$ & $0.028-0.033$ & $6.7 \pm 1.0$ & Bauer (1991) \\
& $635 \pm 246$ & $0.034 \pm 0.008$ & $5.50 \pm 0.63$ & present study \\
L. paulensis & $(227-1360)$ & $(0.013-0.055)$ & $(4.27-6.92)$ & \\
\hline
\end{tabular}


(ANGER; MOREIRA, 1998; MANTEL; DUDGEON, 2005; LARA; WEHRTMANN, 2009), which suggests that this feature may be common in the family. CLARKE et al. (1991) found site-to-site variation for Pandalus borealis showing no significant relationships of reproductive output to female body size in four of six sample localities. Another intraspecific study of two populations of Macrobrachium amazonicum, depicted a higher reproductive output in an inland compared to a coastal population (MEIRELES et al., 2013).

Seasonal variation of reproductive output was shown for Crangon crangon by $\mathrm{OH}$ and HARTNOLL (2004) and two amphipods, Gammarus oceanicus and Echinogammarus marinus, by CLARKE et al. (1985). In the latter study, egg size of both species decreased, whereas overall investment increased as the breeding season proceeded. These results point to a great variety of factors influencing the reproductive output of caridean species. For species with a reproductive output independent of female size we suggest other variables, such as the nutritional condition of a female, the number of broods per reproductive station, population structure and density, temperature or mortality to modulate the energetic investment and thus the reproductive output of a female (SASTRY, 1983; CLARKE et al., 1991).

Brood weight of L. paulensis averages $14.2 \pm 5.4 \%$ of female body weight. This value lies at the low end of the range of previously published data of palaemonids (10.5 - 26.9\%, Table 2) and within the range of other pandalid, crangonid and alpheid shrimp species (9 - 24\%) (see OH et al., 2002 for references). The reproductive output of L. paulensis is very similar to that of Palaemon northropi $(14.4 \pm 2.7 \%)$, a sympatric tropical marine shrimp species also abundant in Brazilian shallow waters (ANGER; MOREIRA, 1998).

Reproductive output underlies a trade-off with growth. This tradeoff has been suggested for some sympatric congeneric species of brachyuran crabs (CARVALHO et al., 2010). However, the lack of comparative studies for many ecological traits and for many groups makes a general statement for Palaemonidae unfeasible. Since brood weight is a combined measure of fecundity and single egg weight (i.e. egg volume) the reproductive output (a measure of brood weight relative to female weight) underlies the ecological factors determining fecundity and egg volume. Over evolutionary time-scales, selection acts on egg size through factors such as food availability or predation risk, whereas overall reproductive investment is determined by feeding conditions for the adult females as ovaries mature (CLARKE et al., 1985). In any given situation, proximate local factors may modulate the extent to which the optimal level of reproductive investment is realized (CLARKE et al., 1991). This makes it very difficult to identify rules and relationships of specific factors. Although necessary to analyze different reproductive strategies and their ecological and phylogenetic relationships, comparative studies of marine, estuarine and freshwater palaemonid species will be challenging since there is strong biological variation among reproductive traits.

Table 2. Comparison of reproductive output (RO) and fecundity in different species of Palaemonidae.

\begin{tabular}{|c|c|c|c|c|}
\hline \multirow{2}{*}{ Species } & \multirow{2}{*}{$\begin{array}{c}\text { RO (\%) } \\
\text { Mean } \pm \text { SD }\end{array}$} & \multicolumn{2}{|c|}{ Fecundity } & \multirow{2}{*}{ Reference } \\
\hline & & Mean \pm SD & $\min -\max$ & \\
\hline Macrobrachium hainanense & $10.5 \pm 3.8$ & 39.1 & $20-75$ & Mantel and Dudgeon (2005) \\
\hline M. carcinus & $12.0 \pm 4.0$ & 98,749 & $14,420-242,437$ & Lara and Wehrtmann (2009) \\
\hline Palaemon gravieri & $12.7 \pm 6.6$ & n.a. & $212-3,989$ & Oh and Park (2000) \\
\hline M. amazonicum (inland) & $14 \pm 6$ & $271 \pm 54$ & n.a. & Meireles et al. (2013) \\
\hline (coastal) & $10 \pm 2$ & $2,237 \pm 586$ & n.a. & \\
\hline P. carinicauda & $14 \pm 9$ & n.a. & $107-1216$ & Oh and Kim (2008) \\
\hline Leander paulensis & $14.2 \pm 5.4$ & $635 \pm 245.95$ & $227-1360$ & Present study \\
\hline P. northropi & $14.4 \pm 2.7$ & n.a. & $172-418$ & Anger and Moreira (1998) \\
\hline \multirow[t]{2}{*}{ P. modestus } & $17.4 \pm 4.6$ & $182 \pm 68$ & $60-353$ & Oh et al. (2002) \\
\hline & $17.5 \pm 8.6$ & n.a. & $254-1,702$ & Oh and Park (2000) \\
\hline P. pandaliformis & $18.6 \pm 3.0$ & n.a. & $102-375$ & Anger and Moreira (1998) \\
\hline M. acanthurus & $19.1 \pm 4.5$ & n.a. & $440-3,042$ & Anger and Moreira (1998) \\
\hline M. olfersii & $21.7 \pm 6.6$ & n.a. & $170-8,960$ & Anger and Moreira (1998) \\
\hline P. paucidens & 27 & $241 \pm 33$ & $195-328$ & Kim et al. (2008) \\
\hline
\end{tabular}

RO values are dry weight estimates; n.a.: no information available. 


\section{CONCLUSION}

Comparison of fecundity and egg size of Leander paulensis with other palaemonids reveals that this species produces a large number of relatively small eggs, with no correlation of investment per reproductive event to female body size. We suggest several extrinsic and intrinsic variables to modulate the reproductive output, such as nutritional condition, temperature or the number of broods per reproductive station. Size and number of eggs of L. paulensis may suggest an extended larval development, as found in many species of Palaemonidae. We showed that females gain weight during egg incubation, which may be a result of a restoration of depleted energy reserves after reproduction. This weight gain must be taken into account when estimating the reproductive output, brood loss in relation to female weight or any other weight-dependent variables of reproduction. The evaluation of several reproductive traits of marine, estuarine and freshwater palaemonids is necessary to generate a comparative analysis of strategies as well as their ecological and phylogenetic relationships.

\section{ACKNOWLEDGEMENTS}

The authors express their deep gratitude to the Faculty of Philosophy, Science and Letters at Ribeirão Preto (FFCLRP), University of São Paulo (USP), to FAPESP (Temático Biota 2010/50188-8) and CAPES (Ciências do Mar II Proc. 2005/2014 - 23038.004308/2014-14) for grant support enabling us to travel to the northern coast of São Paulo and for facilities during the development of the course: Methodologies on Fauna Studies - Invertebrates. We express our thanks to all participants for their help during field activities. FLC and FLM were supported by $\mathrm{PhD}$ and Research fellowships from CNPq (140199/2011-0 and 302748/2010-5; 304968/2014-5, respectively). The collection of specimens conducted in this study complied with current applicable state and federal laws of Brazil (DIFAP/IBAMA/126/05; permanent license to FLM for collection of Zoological Material № 11777-1 MMA/IBAMA/SISBIO).

\section{REFERENCES}

ABELE, L. G.; KIM, W. The decapod crustaceans of the Panama Canal. Smithson. Contrib. Zool., v. 482, p. 1-50, 1989.

ALBERTONI, E. F.; PALMA-SILVA, C.; ESTEVES, F. A. Fecundity of Macrobrachium acanthurus Wiegmann, 1836 (Decapoda: Palaemonidae) in a tropical coastal lagoon subject to human impact (Macaé, Brazil). Acta Limnol. Bras., v. 14, n. 1, p. 71-80, 2002.
ALMEIDA, A. O.; COELHO, P. A.; SANTOS, J. T. A.; FERRAZ, N. R. Crustáceos decápodos estuarinos de Ilhéus, Bahia, Brasil. Biota Neotrop., v. 6, n. 2, p. 1-24, 2006.

ALMEIDA, A. O.; COELHO, P. A.; SANTOS, J. T. A.; FERRAZ, N. R. Crustáceos estomatópodos e decápodos da costa de Ilhéus, Bahia, Brasil. Atlântica, v. 29, n. 1, p. 5-20, 2007a.

ALMEIDA, A. O.; GUERRAZZI, M. C.; COELHO, P. A. Stomatopod and decapod crustaceans from Camamu Bay, state of Bahia, Brazil. Zootaxa, v. 1553, p. 1-45. $2007 \mathrm{~b}$.

AMSLER, M. O.; GEORGE, R. Y. Seasonal variation in the biochemical composition of the embryos of Callinectes sapidus Rathbun. J. Crustac. Biol., v. 4, n. 4, p. 546-553, 1984.

ANGER, K.; MOREIRA, G. S. Morphometric and reproductive traits of tropical caridean shrimps. J. Crustac. Biol., v. 18, n 4, p. 823-838, 1998

ANNALA, J. H. Factors influencing fecundity and population egg production of Jasus species. In: WENNER, A.; KURIS, A. (Eds.). Crustacean egg production. Rotterdam: A. A. Balkema, 1991. p. 301-315.

BALASUNDARAM, C.; PANDIAN, T. J. Egg loss during incubation in Macrobrachium nobilii (Henderson \& Mathai). J. Exp. Mar. Biol. Ecol. v. 59, n. 2/3, p. 289-299, 1982.

BAUER, R. T. Continuous reproduction and episodic recruitment in nine shrimp species inhabiting a tropical seagrass meadow. J. Exp. Mar. Biol. Ecol., v. 127, n. 2, p. 175-187, 1989.

BAUER, R. T. Analysis of embryo production in a caridean shrimp guild from a tropical seagrass meadow. In: Wenner, A.; Kuris, A. (Eds.). Crustacean egg production. Rotterdam: A. A. Balkema, 1991. p.181-191.

BILGIN, S.; SAMSUN, O. Fecundity and egg size of three shrimp species, Crangon crangon, Palaemon adspersus, and Palaemon elegans (Crustacea: Decapoda: Caridea), off Sinop Peninsula (Turkey) in the Black Sea. Turk. J. Zool., v. 30, n. 4, p. 413-421, 2006.

BODDEKE, R. The occurrence of winter and summer eggs in the brown shrimp (Crangon crangon) and the pattern of recruitment. Neth. J. Sea Res., v. 16, p. 151-162, 1982.

CARVALHO, F. L.; SOUZA-CARVALHO, E. A.; COUTO, E. C. G. Comparative analysis of the distribution and morphological sexual maturity of Persephona lichtensteinii and P. punctata (Brachyura, Leucosiidae) in Ilhéus, BA, Brazil. Nauplius, v. 18, n. 2, p. 109-115, 2010.

CARVALHO, F. L.; DE GRAVE, S.; MANTELATTO, F. L. Palaemonetes karukera Carvacho, 1979, a junior synonym of Leander paulensis Ortmann, 1897 (Decapoda, Palaemonidae). Crustaceana, v. 87, n. 13, p. 1586-1590, 2014.

CLARKE, A.; SKADSHEIM, A.; HOLMES, L. J. Lipid biochemistry and reproductive biology in two species of Gammaridae (Crustacea: Amphipoda). Mar. Biol., v. 88, n. 3, p. 247-263, 1985.

CLARKE, A.; HOPKINS, C. C. E.; NILSSEN, E. M. Egg size and reproductive output in the deep-water prawn Pandalus borealis Kroyer, 1838. Funct. Ecol., v. 5, n. 6, p. 724-730, 1991

CLARKE, A. Egg size and egg composition in polar shrimps (Caridea; Decapoda). J. Exp. Mar. Biol. Ecol., v. 168, n. 2, p. 189-203, 1993a.

CLARKE, A. Reproductive trade-offs in caridean shrimps. Funct. Ecol., v. 7, n. 4, p. 411-419, 1993 b. 
CLARKE, A.; GORE, D. J. Egg size and composition in Ceratoserolis (Crustacea: Isopoda) from the Weddell Sea. In: Hempel, G. (Ed.). Weddell Sea Ecology. Berlin: Heidelberg: Springer-Verlag, 1993. p. 129-134.

COELHO, P. A.; ALMEIDA, A. O.; SOUZA-FILHO, J. F.; BEZERRA, L. E. A.; GIRALDES, B. W. Diversity and distribution of the marine and estuarine shrimps (Dendrobranchiata, Stenopodidea and Caridea) from North and Northeast Brazil. Zootaxa, v. 1221, p. 41-62, 2006.

COREY, S.; REID, D. M. Comparative fecundity of decapod crustaceans: I. The fecundity of thirty-three species of nine families of caridean shrimp. Crustaceana, v. 60, n. 3, p. 270294, 1991.

COSTA, R. C.; FRANSOZO, A.; MANTELATTO, F. L.; CASTRO, R. H. Occurrence of shrimp species (Crustacea: Decapoda: Natantia: Penaeidea and Caridea) in Ubatuba Bay, Ubatuba, SP, Brazil. Proc. Biol. Soc. Washington, v. 113, n 3, p. 776-781, 2000.

DA SILVA, R. R.; SAMPAIO, C. M. S.; SANTOS, J. A. Fecundity and fertility of Macrobrachium amazonicum (Crustacea, Palaemonidae). Braz. J. Biol., v. 64, n. 3a, p. 489-500, 2004.

DAVIS, C. C. A study of the hatching process in aquatic invertebrates. XIV. An examination of hatching in Palaemonetes vulgaris (Say). Crustaceana, v. 8, n. 3, p. 233-238, 1965.

DAVIS, C. C. A Study of the Hatching Process in Aquatic Invertebrates. XXIII. Eclosion in Petrolisthes armatus (GIBBES) (Anomura, Porcellanidae). Int. Rev. Gesamten Hydrobiol. Hydrogr., v. 51, n. 5, p. 791-796, 1966.

DE GRAVE, S.; FRANSEN, C. H. J. M. Carideorum catalogus: the recent species of the dendrobranchiate, stenopodidean, procarididean and caridean shrimps (Crustacea: Decapoda). Zool. Meded., v. 85, n. 9, p. 195-589, 2011.

FOX, J.; WEISBERG, S. An R Companion to Applied Regression, Second Edition. Thousand Oaks: Sage, 2011.

JANAS, U.; MAŃKUCKA, A. Body size and reproductive traits of Palaemon elegans Rathke, 1837 (Crustacea, Decapoda), a recent colonizer of the Baltic Sea. Oceanol. Hydrobiol. St., v. 39, n. 2, p. 3-24, 2010.

KIM, J. C.; MA, C. W.; OH, C. W.; PAIK, S. G. Reproduction and growth of the freshwater prawn, Palaemon paucidens (Decapoda: Palaemonidae) in a lake of Korea. J. Environ. Biol., v. 29, n. 2, p. 163-168, 2008.

KURIS, A. M. A review of patterns and causes of crustacean brood mortality. In: Wenner, A.; Kuris, A. (Eds.). Crustacean egg production. Rotterdam: A. A. Balkema, 1991. p. 117-141.

KURIS, A. M.; WICKHAM, D. E. Effect of nemertean egg predators on crustaceans. B. Mar. Sci., v. 41, n. 2, p. 151-164, 1987.

LARA, L. R.; WEHRTMANN, I. S. Reproductive biology of the freshwater shrimp Macrobrachium carcinus (L.) (Decapoda: Palaemonidae) from Costa Rica, Central America. J. Crustac. Biol., v. 29, n. 3, p. 343-349, 2009.

MANNING, R. B. A redescription of the palaemonid shrimp, Leander paulensis Ortmann, based on material from Florida. Bull. Mar. Sci. Gulf Caribb., v. 11, n. 4, p. 525-536, 1961.

MANTEL, S. K.; DUDGEON, D. Reproduction and sexual dimorphism of the palaemonid shrimp Macrobrachium hainanense in Hong Kong streams. J. Crustac. Biol., v. 25, n. 3, p. 450-459, 2005 .
MANTELATTO, F. L.; FRANSOZO, A. Fecundity of the crab Callinectes ornatus Ordway, 1863 (Decapoda, Brachyura, Portunidae) from the Ubatuba region, São Paulo, Brazil. Crustaceana, v. 70, n. 2, p. 214-226, 1997.

MASHIKO, K. Diversified egg and clutch sizes among local populations of the fresh-water prawn Macrobrachium nipponense (de Haan). J. Crustac. Biol., v. 10, n. 2, p. 306314, 1990.

MCCARTHY, L. C.; LOFTUS, W. F.; REHAGE, J. S. Segregation of Palaemonid shrimp along an everglades estuarine gradient: Do multiple species have similar trophic function? Bull. Mar. Sci., v. 88, n. 4, p. 843-861, 2012.

MCCLINTOCK, J. B.; PEARSE, J. S. Organic and energetic content of eggs and juveniles of antarctic echinoids and asterids with lecithotrophic development. Comp. Biochem. Physiol. A: Physiol., v. 85, n. 2, p. 341-345, 1986.

MCEDWARD, L. R.; MORGAN, K. H. Interspecific relationships between egg size and the level of parental investment per offspring in echinoderms. Biol. Bull., v. 200, n. 1, p. 33-50, 2001.

MEIRELES, A. L.; VALENTI, W. C.; MANTELATTO, F. L. Reproductive variability of the Amazon River Prawn, Macrobrachium amazonicum (Caridea, Palaemonidae): influence of life cycle on egg production. Lat. Am. J. Aquat. Res., v, 41, n 4, p. 718-731, 2013

MORAIS, S.; NARCISO, L.; CALADO, R.; NUNES, M. L.; ROSA, R. Lipid dynamics during the embryonic development of Plesionika martia martia (Decapoda; Pandalidae), Palaemon serratus and P. elegans (Decapoda; Palaemonidae): relation to metabolic consumption. Mar. Ecol. Prog. Ser., v. 242, p. 195-204, 2002.

NAZARI, E. M.; SIMÕES-COSTA, M. S.; MÜLLER, Y. M. R.; AMMAR, D.; DIAS, M. Comparisons of fecundity, egg size, and egg mass volume of the freshwater prawns Macrobrachium potiuna and Macrobrachium olfersi (Decapoda, Palaemonidae). J. Crustac. Biol., v. 23, n. 4, p. 862-868, 2003.

OH, C. W.; PARK, K. Y. Comparative study on reproductive effort and spawning frequency of the two palaemonid prawns (Exopalaemon modestus and Palaemon gravieri) with different habitats. J. Fish. Sci. Techn., v. 3, n. 3/4, p. 180-187, 2000.

OH, C. W.; SUH, H. L.; PARK, K. Y.; MA, C. W.; LIM, H. S. Growth and reproductive biology of the freshwater shrimp Exopalaemon modestus (Decapoda: Palaemonidae) in a lake of Korea. J. Crustac. Biol., v. 22, n. 2, p. 357-366, 2002.

OH, C. W.; HARTNOLL, R. Reproductive biology of the common shrimp Crangon crangon (Decapoda: Crangonidae) in the central Irish Sea. Mar. Biol., v. 144, n. 2, p. 303-316, 2004.

OH, C. W.; KIM, J. N. Reproductive biology of Exopalaemon carinicauda (Decapoda, Palaemonidae) in the Hampyong Bay of Korea. Crustaceana, v. 81, n.8, p. 949-962, 2008.

PANDIAN, T. J. Ecophysiological studies on the developing eggs and embryos of the European lobster Homarus gammarus. Mar. Biol., v. 5, n. 2, p. 154-167, 1970.

PAVANELli, C. A. M.; MOSSOLIN, E. C.; MANTELATTO, F. L. Reproductive strategy of the snapping shrimp Alpheus armillatus H. Milne-Edwards, 1837 in the South Atlantic: fecundity, egg features and reproductive output. Invertebr. Reprod. Dev., v, 52, n. 3, p. 123-130, 2008. 
RAMOS-PORTO, M. Revisão das espécies do gênero Leander E. Desmarest que ocorrem no litoral brasileiro. Trab. Oceanogr. Univ. Fed. PE., v. 19, p. 7-26, 1986.

RAMOS-PORTO, M.; COELHO, P. A. Malacostraca - Eucarida. Caridea (Alpheoidea excluded). In: Young, P. S. (Eds.). Catalogue of Crustacea of Brazil. Rio de Janeiro: Museu Nacional, 1998. p. 325-350.

REEVE, M. R. The laboratory culture of the prawn Palaemon serratus. Fish. Invest., v. 26, n. 1, p. 1-38, 1969.

REID, D. M.; COREY, S. Comparative fecundity of decapod crustaceans, II. The fecundity of fifteen species of anomuran and brachyuran crabs. Crustaceana, v. 61, n. 2, p. 175-189, 1991a.

REID, D. M.; COREY, S. Comparative fecundity of decapod crustaceans, III. The fecundity of fifty-three species of Decapoda from tropical, subtropical, and boreal waters. Crustaceana, v. 61, n. 3, p. 308-316, 1991 b.

SASTRY, A. N. Ecological aspects of reproduction. In: Vernberg, F. J.; Vernberg, W. B. (Eds.). The biology of Crustacea. Environmental adaptations. New York: Academic Press, 1983. p. 179-270.

SHAKUNTALA, K.; REDDY, S. R. Crustacean egg size as an indicator of egg fat/protein reserves. Int. J. Invert. Rep. Dev., v. 4, n. 6, p. 381-384, 1982 .
TAMBURUS, A. F.; MOSSOLIN, E. C.; MANTELATTO, F. L. Populational and reproductive aspects of Macrobrachium acanthurus (Wiegmann, 1836) (Crustacea: Palaemonidae) from Southern, Brazil. Braz. J. Aquat. Sci. Technol., v. 16, n. 1, p. 9-18, 2012.

TURNER, R. L.; LAWRENCE, J. M. Volume and composition of echinoderm eggs: implications for the use of egg size in life-history models. In: Stancky, S. E. (Ed.). Reproductive ecology of marine invertebrates. Columbia: University of South Caroline Press, 1979. p. 25-40.

WEAR, R. G. Incubation in British decapod Crustacea, and the effects of temperature on the rate and success of embryonic development. J. Mar. Biol. Assoc. U. K., v. 54, n. 3, p. $745-$ $762,1974$.

WEHRTMANN, I. S.; KATTNER, G. Changes in volume, biomass, and fatty acids of developing eggs in Nauticaris magellanica (Decapoda: Caridea): a latitudinal comparison. J. Crustac. Biol., v. 18, n. 3, p. 413-422, 1998.

ZHAO, Y.; ZHAO, Y.; ZENG, C. Morphogenesis and variations in biochemical composition of the eggs of Macrobrachium nipponense (de Haan, 1849) (Decapoda, Caridea, Palaemonidae) during embryonic development. Crustaceana, v. 80, n. 9, p. 1057-1070, 2007. 